\title{
Safety Measures for Operating Team and Operation Theater During the Current Scenario of COVID-19
}

\author{
Shameen Shoaib ${ }^{1 *}$, Syed Wahajuddin ${ }^{1}$, Sobia Majeed ${ }^{1}$, Sobia Naseem Siddiqui ${ }^{2}$, Afsheen \\ Shoaib $^{3}$, Fauzia Hashmi ${ }^{4}$, Muhammad Jamaluddin ${ }^{1}$, Syed Khurram Fareed ${ }^{2}$ \\ ${ }^{1}$ Abbasi Shaheed Hospital, Karachi, Pakistan. \\ ${ }^{2}$ Dow University of Health Sciences, Karachi, Pakistan. \\ ${ }^{3}$ Darul Sehat Hospital, Karachi, Pakistan. \\ ${ }^{4}$ Jinnah Postgraduate Medical Centre, Karachi, Pakistan.
}

Received: October 5, 2020

Accepted: October 20, 2020

\begin{abstract}
The COVID-19 has become a major threat to Pakistan and worldwide, and has become a significant issue for global health, economy and societies. This rapid spread was occurred from Wuhan, China to most of the part of the world. To elaborate the concept and recommendations regarding the safety precautions in operation theater (O.T) and inside associated team during the current scenario of COVID-19. Many research and review articles were studied to collect information about Covid-19 and strategies published in various journals using the search engine, PubMed and Medline. The COVID-19 has significantly changed all aspects of daily life around the world since very start of this year 2020. SARS-CoV-2 (COVID-19), a novel corona virus, has been infected many healthcare workers. In this perspective, hospitals need a strategy to manage their resources, staff and supplies so that patients receive optimal treatment. A decision tree algorithm was developed that defined the recommendations for safety measures in operation theater and operating procedures, these include identifying and developing an isolation room, administrative measures such as transformations in working flow and procedures, introducing personal protective equipment for the employees and formulating anesthetic clinical guidelines. These control actions are essential to enhance the excellence of care provided to COVID-19 patients and to minimize the risk of spread to other patients or staff. The operating room is a dynamic environment with numerous staff like anesthesiologists, physicians, nurses, O.T attendants and technicians; however, we agree that the containment steps are important in order to improve the standard of treatment provided to COVID19 patients and to minimize the chance of viral spread to patients other than COVID-19 and hospital staff.
\end{abstract}

Key Words: Safety measures, operation theater, Covid-19.

Corresponding Author: Department of Surgery, Abbasi Shaheed Hospital, Karachi, Pakistan. Cell: 03352493696. Email: shameenshoaib@yahoo.com

\section{INTRODUCTION}

In the city of China, Wuhan in December 2019, the novel corona virus SARS-CoV-2 (COVID-19) was detected, after that outbreak of COVID-19 emerged and spread rapidly all over the world [1]. It was soon discovered that a novel coronavirus was responsible, so the novel (new) corona virus was designated as the severe acute respiratory syndrome coronavirus-2 (SARS-CoV-2, 2019-nCoV) due to its high homology ( 80\%) to SARS-CoV, which caused acute respiratory distress syndrome (ARDS) and high mortality during 2002-2003 [2]. The SARS-CoV-2 was considered zoonotic transmission via the sea food commercial sector in Wuhan, China. The disease caused by this virus was called Coronavirus disease 19 (COVID-19) and a pandemic was declared by the World Health Organization (WHO). The WHO declared public health emergency worldwide on 30 January 2020, as a consequence of severe acute respiratory syndrome Coronavirus-2 (SARS-CoV-2) [3]. More than 750, 000 cases have exceeded the capacity across 170 countries on 30 March 2020, with more than 36, 000 reported deaths. Till May 2020, there have been 5, 716, 766 cases around the world, of which 352, 965 deaths have been reported and in Pakistan 59, 151 cases and 1, 225 deaths have occurred, with number of cases on rise every day [4].

Respiratory droplets, contact, fomites and with virus contaminated environment are the likely modes of transmission. Acute respiratory distress syndrome (ARDS) is the outrageous sequel of this disease in severe condition that requires mechanical ventilation. WHO described collective preventive measures for everyone but they are precise and specific for medical personnel as they are front line warriors for treating COVID-19 patients [5]. 


\section{Biosight 2020; 01(02): 1-5}

The concept of this current review is to recommend the precautionary measures in operation theater during the pandemic of COVID 19 situation and also execute the appropriate use of personal protective equipments (PPEs) while ongoing emergency operating procedures. Although the prevalence of COVID-19 suggests that it is spread by droplets, while several literatures support aerosol spread [6, 7]. The Aim of this article to explain measures, discuss these goals including defining and enforcing Operating Room Isolation, improvements in the work ethics, guidance of staff, and provision of clinical guiding principles for anesthetic management.

\section{METHODOLOGY}

Literature study carried out on different articles and review articles to collect information about Covid-19 and surgeries published in various journals using the search engine, PubMed and Medline. Keywords searched include: COVID 19, SARS-CoV 2, pandemic and safety measures for operating team members. The basic objective of this article is to provide the best care of patient from COVID-19 and to minimize the chance of spread to healthcare workers and patients other than COVID-19.

\section{The Hospital Administration Role}

During COVID-19 pandemic several strategies and guiding principles are being established by hospital during all aerosol-generating procedures. Use of PPE which included wearing caps, masks of N95, cover for the pupils, water proof gowns and gloves in COVID-19 suspected cases in accordance with the PPE use guidelines [8, 9]. The training of healthcare workers employed in possible high-risk areas was given to the powerful air purifying respirator. Staff monitoring and temperature recording were required twice a day. Operating group members were typically addressed to learn about the use of powerful air purifying respirator and infection control workflow.

\section{General Care and Intra-Operative Precautions}

The largest viral load of SARS-CoV-2 is in sputum and upper airway secretions, the virus causing COVID-19 [10]. So, the mode of transmission of SARS-CoV-2 is by droplet in nature and not by airborne. Consequently, compliance with droplet precautions and best practices in health, hygienic and sound infection management are indicated. The Centers for Disease Control (CDC) and prevention recommends that airborne isolation areas be reserved for aerosol generating procedure [11]. The standard distance should be predefined from isolation ward to the operating room and moreover isolated elevator must be implemented and least contacts to each other [12]. The whole team responsible for management of emergency case should wear a fitted N95 respirator mask along with droplet PPE (gown, gloves, and eye protection). Standard protocols should be adopted with all patients who are hospitalized. Those patients who match the criteria of SARS-CoV-2 infection were referred to infectious disease specialists. A recent study by Van Doremalen et al., , has found that SARS-CoV-2 may last for as little as 72 hours on plastic and steel surfaces such as elevators button, with the help of a notion that for the transfer of COVID patients one specified and isolated route should be adopted and used [13]. Staff should be instructed to prevent unnecessary journeys to other destinations, and temperatures of every worker should be measured twice daily with digital thermometers and reported to the administrative staff [14].

\section{Operating Room}

With regard to operation theatres, reduction of negative pressure environment to limit the spread of viral particles was suggested in every study $[15,16]$. An air circulation of high-frequency $(25 / \mathrm{hr})$ can significantly reduce the viral load in theatres [8]. For suspected cases of COVID-19, small O.T complex should be designed in a way to enclose three special O.T for surgery. The risk of contamination of other O.T rooms and other patients was minimized by isolation from the main O.T room compound and Elective surgeries of non-COVID-19 patients should be performed in the main theatre. Integrated HEPA filter is fitted in each operation theater room for ventilation purpose and movements to in and out of theatre should be limited with all doors locked to the theatre during the procedure, leaving one possible route through the scrub room for entry / exit. Until starting surgery, all medications and equipment should be prepared to restrict personnel movement in and out of the O.T room [8]. To limit the contact and potential contamination of the trolley, anesthetic medicines should be placed on a tray. In any case, hand washing and glove change are needed than additional supplies from the trolley have to be accessed [12]. In order to decrease the risk of contamination and machines that are difficult to disinfect should be covered by transparent plastic wrap [8]. 
Biosight 2020; 01(02): 1-5

Shoaib et al.,

Anesthesia

Routine monitoring and the cleaning of anesthetic devices as well as efficient respirator systems are included. Relevant areas for the donning and doffing of PPE should be organized and established in a proper way. Whenever possible, anesthetic blockages are to be preferred to prevent airway handling. To prevent aerosol leakage, endotracheal tubes of intubated patients obscured with clamps [8, 12]. Reduce aerosol production by the diligent use of electro cautery and continuous suction, during laparoscopy filter should be used to deflate the pneumoperitoneum $[9,15,17]$.

The number of these staff and their working hours must be as short as possible to minimize patient contact and spread of infection. If intubation is required, rapid sequence intubation is preferable Mask ventilation and aerosolisation must be avoided. Staff should be equipped with FFP filters during laryngoscope and intubation, fiberscope intubations must be avoided if possible [18]. HEPA filter must be used in breathing circuit [connected with patient, between expiratory limb and anesthesia machine circuit and for the protection of gas sampling tube [8, 19].

\section{Personal Protective Equipment (PPE)}

A substantial program was implemented for the use of the PPE. Of the 13 published articles, all recommended the use of eye protection in the form of goggles or a face shield and a filtered face respirator (N95) [15-20]. Double gloves during intubation and/or surgery is recommended in five out of thirteen studies. In order to establish a common algorithm for PPE use in an intervention environment, the hospital management and medical school members have assembled an intervention framework (operating room, intervention suites \& endoscopy) for PPE task force $[8,21,22,23,24]$.

Virus are transmitted by aerosol generating procedures, so therefore intubation and extubation should be attempted with N95 respirators and face shields in both cases of symptomatic and asymptomatic patients. The face shield will cover the N95 against contamination so it can be reuse again. Two pair of gloves should be used and the outer pair should be removed when contaminated [25, 26]. After doffing PPE, the first pair of gloves should be removed, followed by the surgical suit, show covers, cap and goggles. By the help of ear laces, the face mask should be removed so that external side is not affected. It is appropriate to remove the second pair of gloves in the last [19].

All personnel must take a full body shower before switching to clean scrubs, after exit from the theatre. The names of all involved participating staff members should be registered, for easy tracing. After surgery it takes longer to decontaminate, so that the turn-around period is increased $[8,12,21]$.

\section{Postoperative Safety Measures}

The anesthetic breathing circuit and soda lime canister should be abandoned after the surgery to reduce the minimal possibility of circuit contamination and all instruments must send for sterilization and decontamination after surgery. Quaternary ammonium chloride disinfectant wipes are used to clean surfaces in all medical equipment. Operation Theater should be cleaned with 1000ppm sodium hypochlorite and disinfect by vaporization of hydrogen peroxide or ultraviolet $\mathrm{C}$ radiation after surgeries [27-29].

\section{CONCLUSION}

A pandemic preparation involves taking into account the various levels of the controls' hierarchy and different phases of the pandemic. The new SARS-CoV-2 coronavirus pandemic threatens health workers. Recommendations and institutional guidelines for planning and using PPE correctly help to minimize the discomfort and risk of contamination by the team while ensuring patient safety. The operating room is a dynamic environment with numerous stakeholders like anesthesiologists, physicians, nurses, O.T attendants and technicians; aligning the interests and concerns of all parties may be a challenge. However, we agree that these containment steps are important in order to improve the standard of treatment provided toCOVID-19 patients and to minimize the chance of viral spread to patients other than COVID-19 and hospital staff.

\section{ETHICS APPROVAL AND CONSENT TO PARTICIPATE}

Not applicable.

\section{HUMAN AND ANIMAL RIGHTS}

Not applicable. 


\section{Biosight 2020; 01(02): 1-5}

\section{CONSENT FOR PUBLICATION}

Not applicable.

\section{AVAILABILITY OF DATA AND MATERIALS}

None.

\section{FUNDING}

None.

\section{CONFLICT OF INTEREST}

The authors declare no conflict of interest, financial or otherwise.

\section{ACKNOWLEDGEMENTS}

None.

\section{REFERENCES}

1. Huang C, Wang Y, Li X, Ren L, Zhao J, Hu Y, et al., Clinical features of patients infected with 2019 novel coronavirus in Wuhan, China. Lancet 2020; 395: 497-506.

2. Khan Z, Muhammad K, Ahmed A, Rahman H. Coronavirus outbreaks: prevention and management recommendations. Drugs Ther Perspect. (2020) 36: 215-17. doi: 10.1007/s40267-020-0 0717-x.

3. World Health Organization. Statement on the second meeting of the International Health Regulations (2005) Emergency Committee regarding the outbreak of novel coronavirus (2019-nCoV). WHO statement 2020.

4. Worldometers: real-time world statistics. University of Toronto Map and Data Library. Retrieved March 2020.

5. Jayaweera M, Perera H, Gunawardana B, Manatunge J. Transmission of COVID-56219 virus by droplets and aerosols: A critical review on the unresolved dichotomy. Environ Res 2020; 188: doi: 10.1016/j.envres.2020.109819.

6. Van Doremalen N, Bushmaker T, Morris DH, Holbrook M, Gamble A, Williamson B, et al., Aerosol and surface stability of SARS-CoV-2 as compared with SARS-CoV-1. N Engl J Med 2020; doi: 10.1056/ NEJMc2004973.

7. Guan WJ, Ni ZY, Hu Y, Liang WH, OU CQ, He JX, et al., Clinical characteristics of coronavirus disease 2019 in China. N Engl J Med 2020; doi: 10. 1056/NEJMoa2002032.

8. Wong J, Goh QY, Tan Z, Lie SA, Tay YC, Ng SY, Soh CR. Preparing for a COVID-19 pandemic: a review of operating room outbreak response measures in a large tertiary hospital in Singapore. Can J Anesth 2020; doi.org/10.1007/s12630-020-01620-9.

9. Coimbra R, Edwards S, Kurihara H, Bass GA, Balogh ZJ, Tilsed J, et al., European Society of Trauma and Emergency Surgery (ESTES) Recommendations for trauma and emergency surgery preparation during times of COVID-19 infection. Eur J Trauma Emerg Surg 2020; doi.org/10.1007/s00068-020-01364-7.

10. Wang W, Xu Y, Gao R, Lu R, Han K, Wu G, Tan W. Detection of SARS -CoV -2 in different types of clinical specimens. J Am Med Ass 2020. Epub ahead of print 11 March . https: //doi.org/10.1001/jama.2020.3786.

11. CDC. Interim Infection Prevention and Control Recommendations for Patients with Suspected or Confirmed Coronavirus Disease 2019 (COVID- 19) in Healthcare Settings 2020. https: //www.cdc.gov/coronavirus/2019-ncov/healthcare-facilities/ dialysis. Html.

12. Ti LK, Ang LS, Foong TW, Ng BS. What we do when a COVID19 patient needs an operation: operating room preparation and guidance. Can J Anesth 2020; 67. DOI: https: //doi.org/10.1007/ s12630-020-01617-4.

13. Cucinotta D, Vanelli M. WHO declares COVID-19 a Pandemic. Acta Biomed 2020; 91: 157-60.

14. Rajan N, Joshi GP. The COVID-19: role of ambulatory surgery facilities in this global pandemic. Anesth Analg 2020; doi.org/10.1213/ANE.0000000000004847.

15. Forrester JD, Nassar AK, Maggio PM, Hawn MT. Precautions for Operating Room Team Members during the COVID-19 Pandemic. J Am Coll Surg 2020; doi: https: //doi.org/10.1016/j.jamcollsurg.2020.03.030. 


\section{Biosight 2020; 01(02): 1-5}

16. Vukkadala N, Qian ZJ, Holsinger FC, Patel ZM, Rosenthal E. COVID-19 and the otolaryngologistpreliminary evidence based review. Laryngoscope 2020; doi: 10. 1002/ lary.28672.

17. Correia MITD, Ramos RF, Bahten LC Von. Os cirurgiões e a pandemia do COVID-19. Rev Col Bras Cir 2020; 47(1): e20202536.

18. Peng PWH, Ho PL, Hota SS. Outbreak of a new coronavirus: what anaesthetists should know. Br J Anaesth 2020; 124(5): 497-501.

19. Coccolini F, Perrone G, Chiarugi M, Di MF, Ansaloni L, Scandroglio I, et al., Surgery in COVID-19 patients: operational directives. World J Emerg Surg 2020; 15(1): 25.

20. Spinelli A, Pellino G. COVID-19 pandemic: perspectives on an unfolding crisis. Br J Surg 2020; doi: 10.1002/bjs.11627.

21. Di SS, Pata F, Gallo G, Carrano F, Scorza A, Sileri P, et al., Coronavirus pandemic and colorectal surgery: practical advice based on the Italian experience. Colorectal Dis 2020; doi: 10.1111/codi.15056.

22. Givi B, Schiff BA, Chinn SB, Clayburgh D, Iyer NG, Jalisi S, et al., Safety Recommendations for Evaluation and Surgery of the Head and Neck during the COVID-19 Pandemic. JAMA Otolaryngol-Head Neck Surg 2020; 1: doi: 10.1001/jamaoto.2020.0780.

23. Dexter F, Parra MC, Brown JR, Loftus RW. Perioperative COVID-19 Defense. Anesth Analg 2020; 1: doi: 10.1213/ane.0000000000004829.

24. Lui R, Wong S, Sánchez-Luna SA, Pellino G, Bollipo S, Wong M, et al., Overview of guidance for endoscopy during the coronavirus disease 2019 (COVID-19) pandemic. J Gastroenterol Hepatol 2020; doi: 10.1111/jgh.15053.

25. Peng PW, Wong DT, Bevan D, Gardam M. Infection control and anesthesia: lessons learned from the Toronto SARS outbreak. Can J Anesth 2003; 50: 989-97.

26. Christian MD, Loutfy M, McDonald LC, Martinez KF, Ofner M, Wong T, et al., Possible SARS coronavirus transmission during cardiopulmonary resuscitation. Emerg Infect Dis 2004; 10: 287-93.

27. Kamming D, Gardam M, Chung F. Anaesthesia and SARS. Br J Anaesth 2003; 90: 715-8.

28. Tan TK. How severe acute respiratory syndrome (SARS) affected the department of anaesthesia at Singapore General Hospital. Anaesth Intensive Care 2004; 32: 394-400.

29. Wilkes AR, Benbough JE, Speight SE, Harmer M. The bacterial and viral filtration performance of breathing system filters. Anaesthesia 2000; 55: 458-65. 